\title{
UPAYA MENINGKATKAN KEMAMPUAN BERHITUNG PERMULAAN MELALUI METODE JARIMATIKA
}

Humanis Vol 11 No 2

\author{
Asri \\ TK PKK I Gintungan, \\ Kecamatan Kembangbahu, Kabupaten Lamongan \\ Email: asri@gmail.com
}

\begin{abstract}
Abstrak: Tujuan penelitian ini adalah ingin mengetahui kemampuan berhitung anak dengan pendekatan metode jarimatika mudah dan menyenangkan. Sumber data penelitian ini adalah anak TK PKK I Gintungan kecamatan kembangbahu Kabupaten Lamongan sejumlah 15 anak. Penelitian ini tergolong penelitian tindakan kelas yang terdiri dari beberapa siklus dengan setiap siklus terdiri atas perencanaan, tindakan, pengamatan, dan refleksi. Metode penelitian yang digunakan adalah observasi, wawancara, dokumentasi, dan tes. Hasil penelitian menunjukkan bahwa kemampuan berhitung anak melalui metode jarimatika pada studi awal anak paham hanya 4 anak atau $27 \%$ dari seluruh anak.Pada siklus 1 anak paham 7 anak atau 47\%. Prestasi anak dari studi awal ke siklus I anak yang paham bertambah 3 anak atau 20\%.Pada siklus II anak yang paham mencapai $80 \%$ atau 12 anak dari 15 anak. Simpulan penerapan metode jarimatika dapat meningkatkan kemampuan berhitung permulaan anak dengan mudah dan menyenangkan.
\end{abstract}

Kata kunci: kemampuan, berhitung, jarimatika.

PENDAHULUAN

Pendidikan Taman Kanakkanak (TK) merupakan salah satu bentuk pendidikan Anak Usia Dini yang berada pada jalur pendidikan formal, sebagai lembaga pendidikan Prasekolah, tugas utama TK adalah mempersiapkan anak dengan memperkenalkan berbagai pengetahuan, sikap/prilaku, dan ketrampilan agar anak dapat melanjutkan kegiatan belajar yang sesungguhnya di sekolah dasar. Untuk dapat menggali potensi yang dimiliki oleh setiap anak, maka diperlukan adanya usaha yang sesuai dengan kondisi anak masing- masing. Upaya ini bisa dilakukan dengan berbagai macam cara termasuk melalui berhitung permulaan.

Berhitung di TK tidak hanya terkait dengan kemampuan kognitif saja, tetapi juga kesiapan mental sosial dan emosional, karena itu dalam pelaksanaannya harus dilakukan secara menarik, bervariasi dan menyenangkan. Metode berhitung merupakan bagian dari matematika, hal ini diperlukan untuk menumbuhkembangkan ketrampilan berhitung yang sangat diperlukan dalam kehidupan sehari-hari, terutama konsep bilangan yang merupakan juga dasar bagi pengembangan kemampuan matematika maupun kesiapan untuk mengikuti pendidikan selanjutnya (Depdiknas,2007, 1)

Pada kenyataannya, pembelajaran berhitung masih terasa sulit terutama bagi anak usia dini. Hal ini disebabkan oleh beberapa faktor permasalahan baik dari guru, siswa maupun sumber belajar sebagai pendukungnya. Oleh karena itu untuk memecahkan permasalahan tersebut di perlukan penelitian tindak kelas sebagai upaya perbaikan pelaksanaan pembelajaran berhitung permulaan untuk anak TK, hal ini ditandai dengan kondisi sebagai berikut :

1. Dari 15 anak baru 7 anak atau $47 \%$ paham lambang bilangan sedangkan 8 anak atau $53 \%$ belum paham lambang bilangan. 
2. Untuk memahami proses berhitung tambah kurang secara sederhana hanya 5 anak atau $33 \%$ yang paham dan mampu sementara 10 anak atau

$67 \%$ belum mampu dan tidak paham untuk melakukan proses berhitung sederhana.

3. Dari jumlah anak 15 yang mengikuti pembelajaran berhitung sekitar 5 anak atau $33 \%$ sedangkan yang lainnya masih pasif tidak mau mengikuti pembelajaran berhitung. Adapun masalah yang ada pada guru adalah :

1. Metode yang digunakan dalam kegiatan, kurang menarik dan menyenangkan.

Alat peraga dalam pembelajaran masih terbatas.

Oleh karena itu untuk memecahkan permasalahan diatas peneliti mencoba mencari jalan keluar dengan upaya perbaikan pembelajaran melalui penelitian tindakan kelas agar tercipta suasana pembelajaran yang menarik dan dapat memotivasi anak untuk mengikutinya.

Tujuan penelitian ini adalah sebagai berikut.

1. Untuk meningkatkan

kemampuan berhitung permulaan tambah kurang secara sederhana.

2. Untuk meningkatkan kemampuan dan memotivasi anak di kelompok

B TK PKK I Gintungan Tahun Pelajaran

2015/2016 dalam berhitung permulaan melalui metode yang lebih mudah dan menyenangkan.

\section{METODE PENELITIAN}

Penelitian ini dilaksanakan di TKPKK I Gintungan, alasan yang mendasari pemilihan tempat penelitian itu karena aktivitas peneliti sehari-hari, sebagai tenaga pengajar di sekolah tersebut. Penelitian tindakan kelas ini
Humanis Vol 11 No 2

dilaksanakan pada semester 1 tahun pelajaran 2015/2016 selama tiga bulan.

Subjek penelitian tindakan ini adalah anak TK kelompok B sejumlah 17 anak, terdiri dari 11 anak laki-laki dan 6 anak perempuan. Objek penelitiannya adalah proses pembelajaran berhitung permulaan melalui metode jarimatika pada anak kelompok B TK PKK I Gintungan Kecamatan Kembangbahu Kabupaten Lamongan.

Data penelitian yang dikumpulkan berupa informasi tentang kemampuan anak kelompok B TK PKK I Gintungan Kecamatan Kembangbahu Kabupaten Lamongan dalam pembelajaran berhitung permulaan. Untuk mendapatkan data, peneliti menggunakan beberapa teknik dalam proses pengumpulan data: observasi, wawancara, dokumentasi, dan tes.

Teknik analisis data yang digunakan dalam penelitian ini adalah teknik deskriptif komporatif dan analisis kritis, teknik deskriptif komparatif digunakan untuk data kuantitatif, yakni dengan membandingkan hasil antara siklus. Peneliti membandingkan hasil sebelum penelitian dengan membandingkan hasil pada akhir setiap siklus (Suwandi, 2008:70)

\section{HASIL PENELITIAN Siklus I \\ Perencanaan}

Sebelum

melaksanakan

Penelitian

Tindakan Kelas (PTK), peneliti membuat rencana kegiatan pembelajaran agar dalam pelaksanaannya dapat berhasil dengan baik dan sesuai harapan. Peneliti mempersiapkan RKH yang akan dijadikan pedoman dalam melaksanakan langkah-lankgah pembelajaran, serta lembar evaluasi yang digunakan untuk mengukur kemampuan atau prestasi siswa, dan lembar analisis untuk 
mencatat nilai yang diperoleh siswa saat mengikuti pembelajaran tes
Humanis Vol 11 No 2

berhitung permulaan dengan jarimatika.

Tabel 1 Komponen-Komponen yang Dipersiapkan dalam Siklus

\begin{tabular}{|l|l|l|}
\hline No & Komponen & Keterangan \\
\hline 1 & RKH & 1 (satu) set \\
\hline 2 & Lembar pengamatan & Dibuat untuk siswa dan guru \\
\hline 3 & Lembar Evaluasi & Dibuat sejumlah siswa \\
\hline 4 & Lembar Analisis & Dibuat untuk siswa \\
\hline
\end{tabular}

\section{Tindakan}

Setelah semua komponen diatas

dipersiapkan, peneliti dibantu dengan teman sejawat sebagai Observer melaksanakan tindakan perbaikan pembelajaran berhitung permulaan melalui metode jarimatika.

Tindakan perbaikan pembelajaran berhitung permulaan dengan metode jarimatika dilaksanakan dalam dua pertemuan. Pada akhir pertemuan peneliti memberikan review kepada siswa untuk mengetahui seberapa pemahaman dan kemampuan siswa dalam menggunakan jari-jari tangannya sesuai dengan proses berhitung jarimatika yang telah diajarkan. Pelaksanaan tindakan dapat diuruaikan sebagai berikut :

Pertemuan pertama $($ RKH -1$)$

Tahap awal

salam, berdo`a, menyanyi lagu satu tambah satu dilanjutkan dengan bercakap-cakap tentang kegiatan hari ini. Tahap inti

Guru memberi contoh membilang dari 1

- 9 dengan menggunakan yelyel jarimatika yaitu dengan jari-jari tangan, kemudian anak mengikutinya sampai paham dan mampu untuk membuka dan menutup jari-jarinya dengan sempurna. Tahap penutup

Bercerita tentang kegiatan sehari dilanjutkan dengan mengingat yel-yel yang diajarkan kemudian berdo`a, salam, pulang.

Pertemuan ke dua $($ RKH - 2)

Tahap awal

salam, berdo`a, dilanjutkan dengan yel- yel jarimatika.

Tahap inti

Guru memberi contoh membilang cara atau proses berhitung penambahan dan pengurangan dengan jarimatika dari 1 4 dan diikuti oleh anak-anak. Kemudian anak diberi soal untuk diselesaikan bersama-sama dengan guru.

Tahap penutup

Bercerita tentang kegiatan sehari dan postest tambah kurang $1-4$ yang telah diajarkan kemudian berdo`a, salam, pulang.

Pertemuan ketiga $(\mathrm{RKH}-3)$

Tahap awal

salam, berdo`a, yel-yel jarimatika dilanjutkan dengan review tambah kurang dari $1-4$.

Tahap inti Guru memberi contoh membilang dari 5-9 dengan jarimatika diikuti oleh anak dan dilanjutkan dengan menyebutkan hasil tambah kurang dari 5-9 dengan jarimatika sampai paham dan mampu memposisikan jari-jari tangannya dengan sempurna.

Tahap penutup

Bercerita tentang kegiatan sehari postest tambah kurang dari 5 - 9 kemudian berdo`a, salam, pulang.

Pertemuan keempat $(\mathrm{RKH}-4)$

Tahap awal 
salam, berdo`a, yel-yel jarimatika. Tahap inti reiew tambah kurang dari 1 9 dilanjutkan dengan mengerjakan soal dilembar kerja, guru sifatnya mengamati dan membantu anak yang mengalami kesulitan

Tahap penutup

Bercerita tentang kegiatan sehari dilanjutkan dengan postest kemudian berdo`a, salam, pulang.

Pertemuan kelima (RKH - 5)

Tahap awal

salam, berdo`a, review tambah kurang dari $1-9$.

Tahap inti pemberian tugas menyebutkan hasil tambah kurang dari 1 - 9 dilembar kerja dengan guru sebagai pengawasnya.

Tahap penutup

Bercerita tentang kegiatan sehari dilanjutkan dengan postest tambah kurang dar 1 - 9 kemudian berdo`a, salam, pulang.

\section{Pengamatan/Observasi}

Observasi merupakan upaya mengamati pelaksanaan tindakan dalam melaksanakan konteks penelitian tindakan kelas merupakan aktvitas yang dirancang dengan sengaja untuk menghasilkan adanya peningkatan dalam praktek pendidikan dan pengajaran dalam kondisi kelas tertentu. Observasi berfungsi untuk mendokumentasikan pengaruh pelaksanaan tindakan yang dapat diharapkan akan menghasilkan perubahan yang diinginkan. Observasi dilakukan peneliti pada saat pelaksanaan pembelajaran berlangsung dengan mencatat apa saja yang diamati pada saat proses pembelajaran berlangsung kedalam lembar pengamatan yang telah dipersiapkan. Selain itu perencanaan observasi bersifat fleksibel dan terbuka dengan mencatat hal-hal yang tidak terduga ke dalam jurnal, yang berkaitan dengan apa yang terjadi pada saat proses pembelajaran
Humanis Vol 11 No 2

berlangsung.Hasilyangdiperoleh

siswa dalam siklus I yang memenuhi standar kepahaman ada 7 siswa atau 47 $\%$ dari siswa yang berjumlah 15 siswa, sementara yang 8 siswa atau 53 $\%$ yang lainnya belum paham.

\section{Refleksi}

Teman sejawat sebagai observer melakukan pengamatan selama proses kegiatan perbaikan pembelajaran.

\section{Siklus II Perencanaan}

Setelah melaksanakan tindakan perbaikan pembelajaran siklus I yang hasilnya kurang memuaskan maka peneliti melanjutkan melakukan tindakan perbaikan pembelajaran siklus II.

Peneliti mempersiapkan RKH yang akan dijadikan pedoman didalam langkah-langkah pelaksanaan pembelajaran, lembar observasi untuk mencatat kekurangan siswa dan guru selama proses pembalajaran, lembar evaluasi yang digunakan untuk mengukur kemampuan siswa dan lembar analisis untuk mencatat nilai yang diperoleh siswa pada saat melaksanakan tes berhitung tambah kurang dengan jarimatika.

\section{Tindakan}

Masih dibantu teman sejawat sebagai observer, peneliti melaksanakan tindakan perbaikan siklus II.Selama peneliti melakukan tindakan perbaikan, peneliti berpedoman pada RKH dan melihat kekurangan-kekurangan yang ada pada siklus I. Pelaksanaan tindakan dapat diuruaikan sebagai berikut :

\section{Pertemuan pertama $(\mathrm{RKH}-1)$}

Tahap awal salam, berdo`a, yel-yel jarimatika, menyanyi lagu jarimatika.

Tahap inti

Review tambah kurang 1 - 9 dengan jarimatika bersama guru dan anak-anak 
dilanjutkan dengan mengerjakan dengan lembar kerja.

Tahap penutup

Bercerita tentang kegiatan sehari dilanjutkan dengan postest kemudian berdo`a, salam, pulang.

\section{Pertemuan ke dua $(\mathrm{RKH}-2)$}

Tahap awal

salam, berdo`a, menyanyi lagu jarimatika.

Tahap inti

Guru bersama-sama dengan anak membilang $1-9$ dengan yel-yel tambah kurang dilanjutkan dengan pengenalan teman kecil jarimatika.

Tahap penutup

Bercerita tentang kegiatan sehari dan postest teman kecil jarimatika kemudian berdo`a, salam, pulang.

\section{Pertemuan ketiga (RKH - 3)}

Tahap awal

salam, berdo`a, yel-yel jarimatika dilanjutkan dengan menyanyi lagu teman kecil jarimatika.

Tahap inti

Review penambahan teman kecil jarimatika dilanjutkan dengan menyebutkan hasil penambahan dengan teman kecil jarimatika dilembar kerja. Tahap penutup

Bercerita tentang kegiatan sehari postest penambahan teman kecil jarmatika kemudian berdo`a, salam, pulang. Pertemuan keempat $(R K H-4)$

Tahap awal

\section{Siklus I}

Pada studi awal, banyaknya siswa yang mampu berhitung hanya 6 siswa atau $27 \%$ dari 17 siswa yang ada. Hal ini disebabkan karena kurangnya motivasi belajar dan metode pembelajaran yang mudah bagi siswa.Melihat kemampuan berhitung siswa yang demikian kiranya diperlukan tindakan perbaikan pembelajaran yang lebih mudah dan
Humanis Vol 11 No 2

salam, berdo`a, menyanyi lagu teman kecil jarimatika.

Tahap inti

Review penambahan teman kecil jarimatika dilanjutkan dengan menyebutkan hasil penambahan dengan teman kecil jarimatika dilembar kerja. Tahap penutup

Bercerita tentang kegiatan sehari postest penambahan teman kecil jarmatika kemudian berdo`a, salam, pulang.

Pertemuan kelima (RKH - 5)

Tahap awal

salam, berdo`a, review yel-yel tambah kurang, menyanyi lagu teman kecil jarimatika.

Tahap inti

Review tambah kurang $1-9$ dengan jarimatika dilanjutkan menyebutkan hasil tambah kurang dari $1-9$ dengan teman kecil jarimatika.

Tahap penutup

Bercerita tentang kegiatan sehari dilanjutkan dengan postest tambah kurang dari 1 - 9 kemudian berdo`a, salam, pulang.

Pengamatan/Observasi

Teman sejawat yang peneliti minta menjadi observer selama kegiatan tindakan perbaikan pembelajaran materi berhitung permulaan dengan metode jarimatika memberikan hasil pengamatannya.

Refleksi.Setelah tindakan perbaikan pembelajaran selesai dilaksanakan peneliti dan teman sejawat berdiskusi membicarakan hasil tindakan perbaikan pembelajaran.

\section{HASIL PENELITIAN}

menyenangkan bagi siswa sehingga siswa termotivasi untuk mengikutinya dan dapat meningkatkan kemampuan siswa dalam berhitung permulaan.

Pada tindakan perbaikan pembelajaran berhitung permulaan dengan metode jarimatika siklus I diadakan review dan tes untuk 17 siswa dan hasilnya ada 9 siswa (47\%) mampu dan dapat berhitung dengan mudah. Peningkatan 
ini karena dalam tindakan perbaikan pembelajaran peneliti menggunkaan metode jarimatika penambahan dan pengurangan dengan jari-jari tangan untuk alat bantunya dan akan menarik minat anak karena dilakukan dengan paham pada prasiklus dan siklus I.

Tabel 2 Rekapitulasi Mampu dan Tidak Mampu Siswa pada Pembelajaran

Berhitung Permulaan Melalui Metode Jarimatika

\begin{tabular}{|l|l|l|l|}
\hline No & $\begin{array}{c}\text { Kegiatan } \\
\text { Pembelajaran }\end{array}$ & \multicolumn{1}{|c|}{$\begin{array}{c}\text { Siswa mampu } \\
\text { Paham dan mampu }\end{array}$} & $\begin{array}{c}\text { Siswa tidak mampu } \\
\text { Tidak paham }\end{array}$ \\
\hline 1 & Studi awal & 6 siswa $(27 \%)$ & 11 siswa $(73 \%)$ \\
\hline 2 & Siklus I & 9 siswa $(47 \%)$ & 8 siswa $(53 \%)$ \\
\hline
\end{tabular}

Siklus I menemukan beberapa kekurangan baik yang dilakukan siswa maupun guru.

Teman-teman dari observer antara lain

1) Dalam membuka dan menutup jarijari tangannya siswa masih kaku.

2) Masih ragu-ragu dalam berhitung.

3) Keaktifan siswa masih kurang.

4) Penjelasan guru terlalu cepat.

\section{Siklus II}

Menurut observer pada siklus II

terjadi peningkatan yang baik, siswa termotivasi mengikuti pembelajaran berhitung dengan jarimatika karena dilakukan dengan nyanyian dan yel-yel yang mudah dan menyenangkan, siswa yang masih ragu-ragu membuka dan menutup jarinya terlihat lebih mudah gembira, sehingga anak akan merasa senang dan mudah dalam berhitung.

Di bawah ini peneliti akan sajikan hasil observasi dalam tabel rekapitulasi siswa yang paham dan siswa yang tidak

Tabel 3 Rekapitulasi Mampu dan Tidak Mampu Siswa pada Pembelajaran Berhitung Permulaan dengan Metode Jarimatika Studi Awal Sampai Siklus II

\begin{tabular}{|l|l|l|l|}
\hline No & \multicolumn{1}{|c|}{$\begin{array}{c}\text { Kegiatan } \\
\text { Pembelajaran }\end{array}$} & $\begin{array}{c}\text { Siswa mampu } \\
\text { Paham dan mampu }\end{array}$ & $\begin{array}{c}\text { Siswa tidak mampu } \\
\text { Tidak paham }\end{array}$ \\
\hline 1 & Studi awal & 6 siswa (27\%) & 11 siswa (73\%) \\
\hline 2 & Siklus I & 9 siswa (47\%) & 8 siswa (53\%) \\
\hline 3 & Siklus II & 13 siswa (80\%) & 4 siswa (20\%) \\
\hline
\end{tabular}

Dari diagram tersebut jelas terlihat peningkatan kemampuan siswa dalam berhitung dengan menggunakan metode jarimatika yang cukup baik dari siklus I ke siklus II yaitu siswa dan termotivasi untuk terus berhitung. Peneliti lebih sering menggunakan review dengan nyanyian untuk memotivasi dan memudahkan anak untuk menggunakan jar-jari tangannya untuk berhitung.

Setelah diadakan review sambil bernyanyi dan diadakan tes berhitung berulang kali ternyata pada siklus II ini mengalami peningkatan yang baik. Dari

15 siswa yang ada pada kelompok B TK PKK Gintungan Kecamatan Kembangbahu Kabupaten Lamongan yang paham dan mampu berhitung dengan metode jarimatika bisa mencapai

13 anak atau $80 \%$, sedangkan yang belum mampu ada 4 siswa atau $20 \%$. Berikut ini peneliti sajikan dalam bentuk tabel dibawah ini 
temuan tentang keaktifan, dan kemampuan siswa dalam berhitung dengan metode jarimatika masih banyak kekurangannya.Hal ini terbukti baru 9 siswa atau $47 \%$ yang paham berhitung dengan metode jarimatika dari 17 siswa yang ada.

Maka peneliti berencana untuk melakukan tindakan perbaikan pembelajaran siklus II dengan melihat kekurangan-kekurangan yang ada pada siklus I, untuk mengurangi kesalahankesalahan sekecil mungkin.

Untuk memperjelas hasil penelitian, berikut ini data hasil kemampuan siswa dalam berhitung permulaan dengan metode jarimatika dari stadi a wal sampai siklus II.

Tabel 4 Rekapitulasi Mampu dan Tidak Mampu Siswa pada Pembelajaran Berhitung Permulaan dengan Metode Jarimatika Studi Awal Sampai Siklus II

\begin{tabular}{|l|l|l|l|}
\hline No & Kegiatan Pembelajaran & \multicolumn{1}{|c|}{$\begin{array}{c}\text { Siswa mampu } \\
\text { Paham dan mampu }\end{array}$} & \multicolumn{1}{|c|}{$\begin{array}{c}\text { Siswa tidak mampu } \\
\text { Tidak paham }\end{array}$} \\
\hline 1 & Studi awal & 6 siswa $(27 \%)$ & 11 siswa $(73 \%)$ \\
\hline 2 & Siklus I & 9 siswa $(47 \%)$ & 8 siswa $(53 \%)$ \\
\hline 3 & Siklus II & 13 siswa $(80 \%)$ & 4 siswa $(20 \%)$ \\
\hline
\end{tabular}

Berdasarkan hasil kemampuan siswa yang telah mencapai $80 \%$, maka peneliti bersama observer sepakat bahwa penelitian tindakan kelas yang dilaksanakan untuk kelompok B TK PKK I Gintungan Kecamatan Kembangbahu Kabupaten Lamongan berhenti pada siklus II

\section{Pembahasan Hasil Penelitian}

Hasil belajar siswa pada tindakan

perbaikan pembelajaran siklus I meningkat sebesar $20 \%$ atau sebanyak 3 siswa dari hasil belajar siswa pada studi awal. Namun demikian, hasil ini kurang memuaskan peneliti. Harapan peneliti lebih banyak lagi siswa yang akan paham dan mampu menggunakan jari-jari tangannya untuk berhitung permulaan tambah dan kurang sehingga siswa yang paham dan mampu dapat mencapai $75 \%$ sesuai dengan harapan.

Pada pra siklus siswa yang paham hanya 6 siswa atau $(27 \%)$ dari seluruh siswa, pada siklus I siswa yang paham menjadi 9 siswa atau $47 \%$ dari jumlah keseluruhan siswa.Jadi prestasi siswa dari prosiklus ke siklus I siswa yang paham bertambah 3 siswa atau $20 \%$
Ternyata peningkatan pada prestasi siswa juga diimbangi dengan peningkatan kemampuan dan keaktifan siswa dalam mengikuti pembelajaran berhitung permulaan dengan menggunakan metode jarimatika yang hanya menggunakan jari- jari tangan tanpa membebani memori otaknya.

\section{Siklus I}

Observer melakukan monitoring

pelaksanaan pembelajaran berhitung permulaan dengan metode jarimatika untuk mengetahui secara langsung tindakan yang dilaksanakan dalam mengamati saat proses tindakan. Monitoring dilakukan setiap pertemuan sesuai jadwal penelitian.Hasil pengamatan dan catatan dimasukkan sebagai bahan refleksi antara observer dan peneliti untuk melakukan evaluasi selanjutnya.

Hasil observasi dan monitoring pada tindakan kelas siklus I dapat dilaporkan sebagai berikut :

a. Pada siklus I proses pembelajaran berhitung permulaan sudah sesuai dengan perencanaan yang telah disusun.

b. Sebelum pembelajaran, guru memperkenalkan yel-yel dan 
nyanyian TAKU (tambah kurang) dengan jari tangan agar anak termotivasi dan tertarik untuk berperan secara aktif dalam kegiatan pembelajaran dan anak memahami posisi jari dalam berhitung dengan jarimatika.

c. Guru berusaha menjadi fasilitator dan mediator dalam pelaksanaan.

d. Guru melakukan evaluasi secara individu yaitu dengan memberikan simulasi penerapan jarimatika dalam penyelesaian soal-soal sederhana.

\section{Aktivitas Siswa}

1) Aktivitas siswa dalam pembelajaran

berhitung permulaan pada siklus I, terlihat bahwa siswa sangat antusias dalam mengikuti pembelajaran, siswa senang dengan buka tutup jari tangannya dan semangat dalam menjawab pertanyaan guru.

2) Motivasi siswa dalam belajar berhitung dengan metode jarimatika sudah cukup tinggi, hal ini terlihat dari keaktifan siswa untuk mengikuti berhitung bersama dengan gembira dan selalu menanyakan apakah betul hasilnya ini, kepada peneliti dan observer. Namun masih ada siswa yang dengan perasaan ragu-ragu untuk membuka dan menutup jarinya, setelah didekati dan diberi bimbingan siswapun mulai merasakan mudahnya berhitung dengan jarimatika.

3) Secara keseluruhan aktifitas siswa pada siklus I belum mencapai target yang diharapkan, karena tingkat keaktifan siswa belum maksimal.

Hasil kemampuan dan motivasi anak untuk mengikuti pembelajaran berhitung pada siklus I belum sesuai dengan harapan peneliti karena belum mencapai target kemampuan yang diharapkan, maka peneliti bersama teman sejawat melanjutkan tindakan perbaikan pembelajaran pada siklus II.

\section{Siklus II}

Tindakan perbaikan pembelajaran pada siklus II dengan menggunakan yel- yel tambah kurang jarimatika dan nyanyian sangat memotivasi siswa untuk mengikuti pembelajaran berhitung permulaan, sehingga siswa dapat dengan mudah dan senang menggunakan jarijari tangannya untuk berhitung.

Pada hasil review dan tes akhir siklus II, kemampuan dan pemahaman siswa dalam belajar berhitung permulaan dengan metode jarimatika telah terpenuhi yaitu dari 17 siswa yang mampu dan paham berhitung dengan metode jarimatika mencapai 13 siswa atau $80 \%$, sehingga perbaikan pembelajaran berhitung permulaan berhenti pada siklus

II.

Tindakan perbaikan pembelajaran berhitung permulaan dengan metode jarimatika pada anak kelompok B TK PKK I Gintungan Kecamatan Kembangbahu Kabupaten Lamongan telah selesai sampai pada siklus II, dari hasil pengamatan dan tes yang telah dilaksanakan, pembelajaran berhitung berjalan dengan lancar dan mendapatkan hasil sesuai dengan yang diharapkan. Dari hasil penelitian, observer bersama peneliti mendapatkan beberapa temuan- temuan dari hasil tindakan perbaikan pembelajaran berhitung permulaan yaitu : a. Anak menjadi paham proses berhitung tambah kurang permulaan yang sederhana.

b. Anak paham dan mampu menggunakan jari-jari tangannya untuk berhitung jarimatika.

c. Anak menjadi semangat dalam belajar berhitung.

Hal ini terbukti dari studi awal sampai siklus II anak yang paham dan mampu belajar berhitung 
permulaan dengan metode jarimatika mencapai 13 anak atau $80 \%$,

\section{PENUTUP}

\section{Simpulan}

Berdasarkan temuan dan hasil yang diperoleh dapat ditarik kesimpulan sebagai berikut :

1. Upaya meningkatkan kemampuan anak dalam berhitung permulaan melalui metode jarimatika pada kelompok B TK PKK I Gintungan Kecamatan Kembangbahu Kabupaten Lamongan, telah memberikan hasil yang memuaskan. Hal tersebut terbukti dari rekapitulasi penilaian kemampuan anak dalam berhitung menggunakan metode jarimatika. Pada studi awal hanya 4 anak atau

27\% dari 15 siswa, pada siklus I siswa yang mampu dan paham mencapai $47 \%$ atau 7 anak, jadi prestasi siswa dari studi awal ke siklus I bertambah 3 anak atau $20 \%$. Peningkatan kemampuan siswa dalam berhitung menggunakan metode jarimatika yang cukup baik terlihat pada siklus II yaitu mencapai $80 \%$ atau 12 anak dari 15 siswa.

2. Motivasi siswa dalam pembelajaran berhitung permulaan melalui metode jarimatika pada anak kelompok B TK PKK I Gintungan Kecamatan Kembangbahu Kabupaten Lamongan, juga mengalami peningkatan, hal ini dikarenakan berhitung dengan metode jarimatika dilakukan dengan menggunakan nyanyian dan yel-yel yang tidak membebani memori otak anak, sehingga anak merasa senang dan tidak terbebani.

3. Belajar berhitung dengan menggunakan metode jarimatika relatif tidak memberatkan memori otak, karena diberikan secara menyenangkan maka sistem linbik diotak anak akan senantiasa terbuka sehingga memudahkan anak dalam menerima materi baru dan ini merupakan langkah awal membangun rasa percaya diri anak untuk lebih jauh menguasai ilmu matematika seperti yang diungkapkan oleh Septi Peni Wulandani (2004,www.jarimatika.com).

\section{Saran}

1. Bagi siswa diharapkan agar metode jarimatika selalu dipakai dalam pembelajaran berhitung permulaan

2. Diharapkan kepada kepala sekolah dapat menerapkan metode jarimatika menjadi salah satu kurikulum Tingkat satuan pendidikan dalam pengembangan pembelajaran berhitung.

3. Mengingat pelaksanaan penelitian ini hanya berjalan 2 siklus, maka peneliti atau guru lain diharapkan dapat melanjutkan untuk mendapatkan temuan-temuan yang lebih kompleks dan memuaskan.

4. Pelaksanaan kegiatan pembelajaran berhitung untuk meningkatkan kemampuan anak kelompok B TK PKK Gintungan Kecamatan Kembangbahu Kabupaten Lamongan ini, dalam penelitiannya masih kurang optimal dan sempurna sebagai penelitian yang ideal.

5. Kegiatan berhitung permulaan untuk motivasi dan meningkatkan kemampuan siswa akan berhasil jika dilakukan dengan senang, gembira dan mudah tanpa membebani anak serta menggunakan metode yang sesuai dengan dunia anak.

6. Kepada Depdiknas dimohon untuk merespon dan menindak lanjuti 
hasil observasi pembelajaran berhitung permulaan dengan metode jarimatika di TK PKK I Gintungan Kecamatan Kembangbahu Kabupaten Lamongan dikaji lebih jauh kemungkinan untuk diterapkan pada pendidikan pra sekolah.

\section{DAFTAR PUSTAKA}

Anggora M.Toha, dkk (2008). Metode Penelitian, Jakarta : Universitas Terbuka

Anonim .2011"Pengertian Uji Validitas Data" UT UPBJJ Purwokerto, diakses (Minggu 23 Oktober 2011,21.30) di Depdiknas (2007). Permaianan Berhitung Permulaan. Jakarta.

Ian. 2011."Pengertian Tentang Kemampuan". UT.UPBJJ

Purwokerto. Diakses Selasa, 4 Oktober 2011, $\quad 14.30$

di

http://www.ian43.wordpress.co

$\underline{\mathrm{m}}$

Kayvan Umy 2009.57 Permainan Kreatif untuk Mencerdaskan

Anak. Jakarta: Media Kita.

Lestari Ririn Anggia, FIB UI (2009), UT UPBJJ Purwokerto diakses (Minggu 23 Oktober 2011, 21.45) di

http://www.teorionline.wordp r ess.com/2010/01/24/

Pekerti Widia, dkk.2010., Metode Pengembangan Seni (PGTK 2402). Jakarta : Universitas Terbuka.

http://www.scribd.com/doc/54258199/2 1/ Uji-validitas-data

Pengertian Uji Validitas Data UT UPBJJ Purwokerto, diakses (Minggu 23

Oktober 2011, 21.30)

$\underline{\text { di }}$

http://www.scribd.com/doc/5425

8199/21/Uji-validitas-data
Sujono Yuliani Nurani, dkk $2009 . \quad$ Metode Pengembangan Kognitif. (PGTK2101) Jakarta : Universitas Terbuka.

Tim PKP PG PAUD. 2008. Panduan Pemantapan Kemampuan Profesional. Jakarta : Universitas Terbuka.

Wardani IGAK, dkk. 2008. Penelitian Tindakan Kelas. Jakarta : Universitas Terbuka.

Wulandani Septi Peni. 2004. Jarimatika, Penambahan dan Pengurangan. Kawan Pustaka. (UT. UPBJJ Purwokerto. Diakes (minggu/23 oktober 2011, 21.00) di http://www.jarimatika.com 